\title{
Retention or defection? Chinese consumers' decision-making styles for domestic and global brands
}

\author{
S.Y. Tzeng a and W.M. Wong ${ }^{\mathrm{b} *}$ \\ a Business School, Shantou University, 243 Daxue Road, Shantou, Guangdong, P.R., 515063, China \\ ${ }^{\mathrm{b}}$ School of Business and Management, University College of Technology Sarawak, 868 Persiaran Brooke, Sibu Sarawak, 96000 , \\ Malaysia
}

*To whom all correspondence should be addressed wmwong@ucts.edu.my

\begin{abstract}
This study explores consumers' decision-making in terms of intention to switch to foreign brands from domestic brands when purchasing cell phones and sports shoes. A survey of 584 undergraduates in Guangdong, China, shows that domestic brands retain their low quality-conscious, low fashion-and-recreational-conscious and low price-conscious customers and attract low brand-conscious and high choice-confused buyers from foreign brands. Foreign brands typically retain their consumers who are highly conscious of fashion and recreation and keep and draw customers with low choice confusion. High-price-conscious consumers and those who are highly brand-confused will assess foreign and domestic brands when searching for bargains. Regarding managerial implications, local brands should offer products of high quality at low prices and constantly invest in R\&D; foreign brands may expand their customer bases and build interactive brand channels; all companies can retain brand-confused customers with preferential packages and design their marketing strategies based on decision-making styles of their target consumers.
\end{abstract}

\section{Introduction}

Competition between international and local brands is intense in China. Traditionally, Chinese consumers have strong preferences for western and Japanese brands for their quality, status and/or symbolic value (Delong, Bao, Wu, Chao \& Li, 2004; Sin, Ho \& So, 2000). However, this trend is changing. According to Epsilon's survey (2013), although many respondents still favor foreign brands, the proportion of those supporting local brands increased significantly from $15 \%$ in 2011 to $23 \%$ in 2013. This change in Chinese brand preferences deserves further attention.

Customers' experiences with current products influence their intentions to switch (Kim \& Srinivasan, 2009: 279). Intention to switch brands is a signal for marketers, indicating whether their marketing strategies are effective. Numerous studies have effectively identified factors influencing switching intention, and most have identified customer satisfaction, switching cost and the availability of attractive alternatives as primary reasons (Colgate, Tong, Lee \& Farley, 2007: 224; Kim, Shin \& Lee, 2006: 886-887; Bansal, Taylor \& James, 2005: 110-112; Varki \& Colgate, 2001). However, these factors do not always guarantee customer retention (Naumann, Haverila, Khan \& Williams, 2010: 878-879; Omotayo \& Jachim, 2008: 28-29; Garbarino \& Johnson, 1999: 81-83; Reichheld, 1996). Switching intention is directly impacted by a consumer's attitude towards a product or service (Pookulangara, Hawley \& Xiao, 2011: 195-196; Ganesh, Arnold \& Reynolds, 2000). Hence, how customers perceive their relationship to a service or product is as essential as those external factors.

Consumers' decision-making styles are decision-related attitudes consumers adhere to, even when goods and services differ (Walsh, Mitchell \& Hennig, 2001: 90-91). These attitudes appear to influence their intention to stay with or switch from a brand's products or services (Dick \& Basu, 1994:100-102; Keller, 1993:1-2), which may account for part of the switching intention inexplicable for the external reasons suggested by past studies. Although decision-making style is a powerful determinant of switching intention, rarely has it been investigated. The study explores the impact of the decision-making styles of Chinese consumers' intentions to switch from domestic brands to foreign brands. Some important questions warrant answers. First, without price consideration, would customers switch from their current brands? Second, how do decision-making styles influence switching intention? Third, do demographic factors influence switch intention?

\section{Literature review}

\section{Chinese consumer's perceptions of local and international brands}

Consumers' brand choice varies in both developing and developed countries (Wang, Siu \& Hiu, 2002: 239). In developed countries, the quality of domestic products is expected to be higher than that of imported products. In contrast, foreign products are considered superior in the 
developing countries (Wang et al., 2002: 239; Batra, Ramaswamy, Alden, Steenkamp \& Ramachander, 2000: 8486). This phenomenon supports the notion that consumers believe that products from less-developed countries have lower quality, and higher risk of performing poorly, resulting in dissatisfaction (Cordell, 1991: 127-128). Consumers believe trusted brands are reliable. Brand trust is significantly influenced by a consumer's evaluation via direct (e.g., trial, usage), and indirect contact (e.g., advertising, word of mouth) with a brand (Krishnan, 1996: 394).

Chinese consumers' preference for international brands has been widely studied (Delong et al., 2004: 143-144; Laforet \& Chen, 2012: 54-55). Chinese brands typically struggle to develop brand trust, and also face intense competition and product surpluses in their domestic market (Fan, 2006: 366368). However, Chinese consumers have retained their strong preference for foreign brands (Sin et al., 2000; Delong et al., 2004; Wu \& Delong, 2006: 239; Wang \& Yang, 2008: 470). For instance, Wang \& Yang (2008: 470) conducted a crosscity survey of auto brand preferences in China. After interviewing 1200 respondents, they found that German's brands exerted significant main effects on the purchase intention of Chinese consumers. Ding (2013: 38), who investigated preferences of urban adult Chinese consumers for foreign and Chinese products, identified the top three reasons for the preference for foreign products: superior quality, better design and superior brands.

As China is developing rapidly, Chinese consumers are becoming more sophisticated and diverse. Chinese consumers can no longer be regarded as favoring foreign products (Zhou \& Hui, 2003: 36; Dickson, Lennon, Montalto, Shen \& Zhang, 2004: 313-314; Laforet \& Chen, 2012: 6162). Low-income residents favor Chinese brands because they are often affordable (Laforet \& Chen, 2012: 61-62). Quality improvements to domestic products also challenge the dominance of foreign products (Zhou \& Hui, 2003: 37). Hence, improved quality with lower price makes Chinese products more competitive than foreign ones.

\section{Switching intention}

Switching intention is a customer's psychological tendency to stop using a brand and start using another brand (Keaveney, 1995: 71-72). Client retention helps businesses boost and sustain profit. As the time a customer stays with a brand increases, the utility that a customer generates increases (Reichheld \& Sasser, 1990: 109). Hence, companies that do not want to lose consumers must be cognizant of switching reasons and generate strategies to combat them.

Though factors influencing switching intention have been identified as satisfaction, costs and alternatives (Colgate et al., 2007: 224; Kim, et al., 2006: 886-887; Bansal et al., 2005: 110-112; Varki \& Colgate, 2001), they still face some challenges. Reichheld (1996) suggested that some unsatisfied customers may still stay with a brand because they do not expect better service elsewhere. Naumann et al. (2010), who conducted a two-step study in the facilities-management industry, showed that approximately $90 \%$ of defecting companies were satisfied with their current business partners but switched to another service provider within one year. They concluded that in a highly commoditized, homogeneous market, a lower price drives the switches. The finding is also supported by other investigations (Varki \& Colgate, 2001: 238).

Studies have shown that attitude toward a given behavior affects intention to perform that behavior (Ajzen, 1991; Taylor \& Todd, 1995). Customers' attitudes toward brands, loyalty, or other value-related aspects affect their intention to switch from a brand's products or services (Dick \& Basu, 1994: 100-102; Keller, 1993: 1-2).Some highly-involved customers become more loyal to the brand, more committed to their own judgments and less focused on service failures (Pritchard, Havitz \& Howard, 1999: 344). Colgate et al. (2007: 222) collected data from 24 in-depth interviews and nearly 700 questionnaires and proposed that Chinese customers tend to maintain a brand relationship because of the legacy of Confucianism. Therefore, in terms of switching intention, how customers perceive their relationship with services or products is very meaningful. Consumer decisionmaking styles influence shopping attitudes and behaviors and are "basic attitudes that consumers adhere to, even when they are applied to different goods, services or purchasing decisions" (Walsh et al., 2001:90-91).

\section{Decision-making styles}

Though consumers' purchase intention is affected by many factors, decision-making style is crucial (Tanksale, Neelam \& Venkatachalam, 2014: 212-213; Bandara, 2014: 4). Sproles and Kendall (1986) defined consumer decision-making style as "a mental orientation characterizing a consumer's approach to making choices." They further developed a Consumer Styles Inventory (CSI) comprising the following eight attributes.

1. Perfectionist/ Quality Conscious: cautiously and systematically seeking products with the best quality.

2. Brand Conscious/Price Equals Quality: orientated to purchasing the more expensive, well-known brands.

3. Novelty and Fashion Conscious: favoring new and innovative products and seeking the excitement associated with the search for new things.

4. Recreational and Shopping Conscious: considering shopping a pleasant activity.

5. Price Conscious/ "Value for Money": particularly conscious of sale prices and low prices in general;

6. Impulsive, Careless: tending to buy on the spur of the moment and less concerned with the money they spend or getting "best buys".

7. Confused by Overchoice: being burdened with too many brands, stores and market information.

8. Habitual Brand Loyal: favoring specific brands and stores, and forming related choice habits.

The CSI has been applied widely in countries such as China, Germany, Greece, India, Korea, Malaysia, New Zealand, the 
UK and the US (Hafstrom, Chae \& Chung, 1992; Lysonski, Durvasula \& Zotos, 1996; Mitchell \& Bates, 1998; Walsh et al., 2001, Mokhlis, 2009). Some authors argued that this eight-factor solution was more applicable to developed countries, such as New Zealand and the United States, and was not as applicable to India or Greece (Lysonski et al., 1996: 18-20). Other researchers suggested that the CSI does not fit perfectly consumers in Korea and Germany (Hafstrom et al., 1992; Walsh et al., 2001: 91). Although the inventory can be applied to different cultures and generate meaningful results, findings cannot be generalized to different cultures (Mitchell \& Bates, 1998: 215-218; Walsh et al., 2001: 91).

Previous studies also discussed Chinese decision-making styles as they relate to preferences for foreign or local brands. Wang, et al. (2002: 248) asserted that recreation-andshopping conscious consumers preferred imported brands to domestic brands. Dickson et al. (2004: 306-314), who surveyed 1628 consumers in Beijing, Guangzhou, and Shanghai, discovered that consumers who focus on price and quality prefer western brands. Wang et al. (2002: 248) interviewed 431 respondents in Guangzhou, and concluded that brand, quality and fashion conscious consumers prefer western brands of clothing. All these past empirical findings indicate that foreign brands seem to be favored by Chinese consumers with different kinds of decision-making styles, which may lead to purchasing switches for local-brand buyers and brand retention for international product buyers in China. Hence, two hypotheses are proposed:

Hypothesis 1: The stronger decision-making styles the foreign-brand buyers possess, the more possibly that they would stay with foreign products.

Hypothesis 2: The stronger decision-making styles the local-brand buyers possess, the more possibly that they would defect to foreign products.

\section{Methodology}

This study focuses on the decision-making styles of university students when they purchase cell phones and sports shoes based on the following reasons. First, these young adults have buying power and good potential to increase their buying power (Jurisic \& Azevedo, 2011; Tanksale et al., 2014: 213). Second, university students have been identified as one of the most important markets for cell phones (Jurisic \& Azevedo, 2011; Totten, Lipscomb, Cook \& Lesch, 2005) and sportswear (Wong \& Yahyah, 2008). Third, different retail businesses may be related to different decision-making styles (Lysonski et al., 1996: 18-19). Cell phones and sports shoes are common among university students, but also represent technology and fashion.

\section{Sample and procedure}

In total, 628 surveys were distributed electronically to undergraduate students in Guangdong, China. After removing incomplete questionnaires, 584 questionnaires were collected. Table 1 summarizes demographic data.
Overall, the sample generally had an equal number of males $(50.4 \%)$ and females $(49.6 \%)$. Few seniors $(3.60 \%)$ were in the sample because most were off campus for their internships. On average, monthly disposable income was around 900RMB (approximately US\$150).

\section{Table 1: Demographic profile of the sample}

\begin{tabular}{llcl}
\hline Variable & Description & Frequency & Percent (\%) \\
\hline Gender & Male & 294 & 50.40 \\
& Female & 290 & 49.60 \\
\hline Education & Freshman & 257 & 44.00 \\
Level & Sophomore & 123 & 21.10 \\
& Junior & 183 & 31.30 \\
& Senior & 21 & 3.60 \\
\hline Monthly & 599RMB and below & 109 & 18.70 \\
disposable & 600RMB-899RMB & 212 & 36.30 \\
income & 900RMB-1199RMB & 167 & 28.60 \\
& 1200RMB and above & 96 & 16.40 \\
\hline
\end{tabular}

\section{Measures}

All 39 items from the CSI, which are listed in Appendix 1, were translated into Chinese. This scale has been validated by many studies in different countries (Mitchell \& Bates, 1998; Walsh et al., 2001; Mokhlis, 2009). All responses were on a five-point Liker scale, ranging from 1 for "strongly disagree" to 5 for "strongly agree".

To survey undergraduates' consideration of cell-phone and sports-shoe purchases, this study developed several questions. First, items "What brands are your current cell phones and sports shoes? " and "Which brands of cell phones and sports shoes would you buy if your economic condition permitted?" were used to identify switching intention and exclude the price factor. Accordingly, respondents then choose brands from a list of local and foreign brands sold in China. Figure 1 and Figure 2 list the percentage of ownership and purchase intention of foreign and domestic cell phones and sports shoes, respectively. In total, $64 \%$ of respondents owned a foreign cell phone and willingness to purchase foreign brands was as high as $89 \%$. In contrast, $46 \%$ of undergraduates used Chinese cell phones, and $40 \%$ tended to buy Chinese cell phones. Only $45 \%$ of respondents owned foreign sports shoes; the percentage of willingness to purchase foreign brands will increase to $79 \%$. Although $69 \%$ of respondents owned Chinese shoes, only $47 \%$ wanted to stay with Chinese brands.

Second, to elucidate purchase reasons, the item "What is your first consideration when buying cell phones and sports shoes?" The list of possible answers was: (1) price, (2) quality, (3) multifunction, (4) fashion, (5) promotion, (6) brand, (7) after sale service and (8) others. Table 2 shows item results. The first three factors for cell phones were quality $(36.19 \%)$, price $(24.13 \%)$ and brand $(13.33 \%)$, and for sports shoes they were quality $(55.40 \%)$, price $(20.16 \%)$ and promotion $(9.37 \%)$. Undergraduates typically favor good quality and low price; they also care most about brand for their cell phones and about promotion for their sports shoes. 


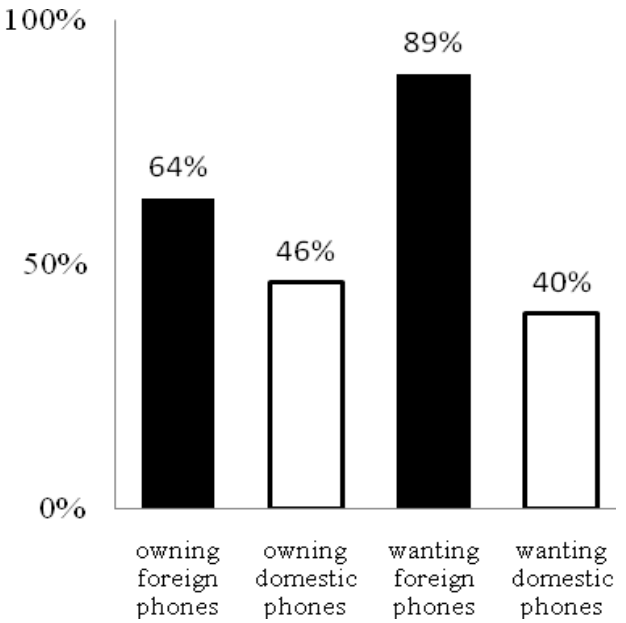

Figure 1: Percentage of ownership and purchase intention of foreign and domestic cell phones

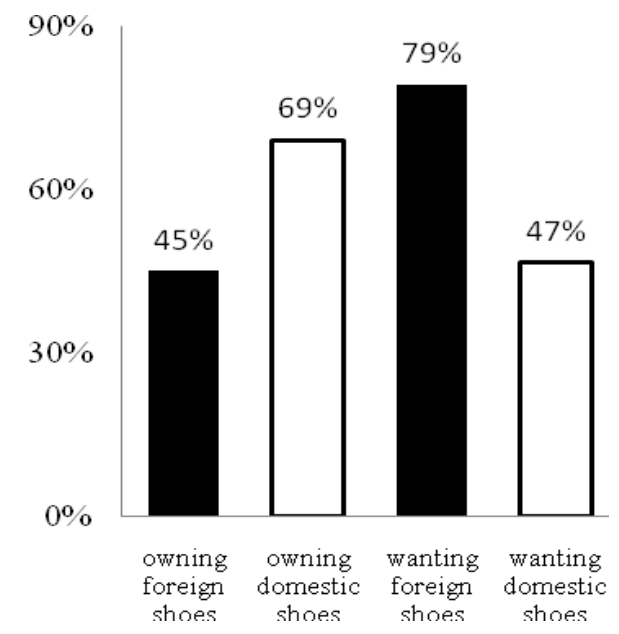

Figure 2: Percentage of ownership and purchase intention of foreign and domestic sports shoes

Table 2: Considerations for buying cell phones and sports shoes

\begin{tabular}{llrl}
\hline & Considerations & Cell phones & Sports shoes \\
\hline 1 & Price & $24.13 \%$ & $20.16 \%$ \\
2 & Quality & $36.19 \%$ & $55.40 \%$ \\
3 & Multifunction & $12.22 \%$ & $1.59 \%$ \\
4 & Fashion & $4.76 \%$ & $2.22 \%$ \\
5 & Promotion, & $2.86 \%$ & $9.37 \%$ \\
6 & Brand & $13.33 \%$ & $0.48 \%$ \\
7 & After sale service & $1.11 \%$ & $6.67 \%$ \\
8 & Others & $5.40 \%$ & $4.13 \%$ \\
\hline
\end{tabular}

To deeply understand the effects of respondents' decisionmaking styles on their switching intentions, five brand-choice packages are proposed as dependent variables.
1. Retention of domestic and foreign brands (FDtoFD): owning both foreign and domestic brands (or only possessing one) and willingly to purchase foreign and domestic brands in the future.

2. Retention of foreign brands (FtoF): currently owning foreign brands and only willingly to purchase foreign ones in the future.

3. Retention of domestic brands (DtoD): currently owning domestic brands and only willingly to purchase domestic brands in the future.

4. Defection from domestic to foreign brands (DtoF): currently owning domestic brands (or also owning foreign brands) but only willingly to purchase foreign brands in the future.

5. Defection from foreign to domestic brands (FtoD): currently owning foreign brands (or even owning domestic brands) but only willingly to purchase domestic brands in the future.

Switching intention is coded as 0 (no) or 1 (yes). For example, if the procedure predicts its estimate of probability is FtoF, it is coded 1 ; otherwise, 0 .

\section{Empirical results and discussion}

\section{Exploratory factor analysis}

Exploratory factor analysis extracted seven factors with eigenvalues $>1.0$; however, 11 items did not contribute to factor definitions and three items were dropped due to crossloadings. The remaining 25 items were again analyzed. The three items for novelty/fashion consciousness and two for recreational/hedonistic consciousness had significant factor loadings on the same factor (fashion-and-recreation conscious). The final seven-factor solution accounted for approximately $64 \%$ of total variance. Table 3 presents the pattern matrix showing the items, factor loadings and their variance explained. These factors reflect seven characteristics of the CSI among Chinese university students: confused by overchoice, fashion-and-recreation conscious, quality conscious, brand conscious, brand loyal, price conscious and impulsive.

\section{Logistic regression}

To determine the decision-making styles related to consumers' brand switch intention, binary logistic regression analysis was conducted. Binary logistic regression is a type of regression where the dependent variable is a dummy variable with two possible outcomes. In the models of this study, switching intention is coded dichotomously and seven continuous covariates, CSI factors, and two categorical covariates- gender and education level- are considered as the predictors. Tables 4 and 5 show the results of the forward selection procedures. Except the FtoF model in Table 4, all models are significant with correct classification rates $>70 \%$. 
Table 3: Exploratory factor analysis results of decision-making styles

\begin{tabular}{|c|c|c|c|}
\hline Factor Name & 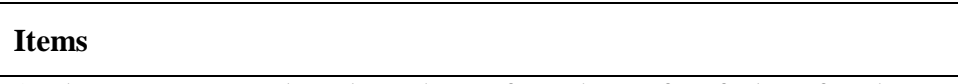 & $\begin{array}{l}\text { Factor } \\
\text { Loadings } \\
\end{array}$ & $\begin{array}{l}\text { Variance } \\
\text { Explained (\%) } \\
\end{array}$ \\
\hline \multirow{4}{*}{$\begin{array}{l}\text { Factor 1: } \\
\text { Confused by } \\
\text { overchoice }\end{array}$} & 1. There are so many brands to choose from that I often feel confused. & 0.76 & \multirow[t]{4}{*}{22.22} \\
\hline & 2. Sometimes it's hard to choose which stores to shop. & 0.80 & \\
\hline & 3. The more I learn about products, the harder it seems to choose the best. & 0.81 & \\
\hline & 4. All the information I get on different products confuses me. & 0.78 & \\
\hline \multirow{5}{*}{$\begin{array}{l}\text { Factor 2: } \\
\text { Fashion and } \\
\text { recreational } \\
\text { conscious }\end{array}$} & 1. Fashionable, attractive styling is very important to me. & 0.65 & \multirow[t]{5}{*}{11.00} \\
\hline & 2. To get variety, I shop different stores and choose different brands. & 0.76 & \\
\hline & 3. It's fun to buy something new and exciting. & 0.78 & \\
\hline & 4. Shopping is not a pleasant activity to me. & 0.70 & \\
\hline & 5. I enjoy shopping just for the fun of it. & 0.56 & \\
\hline \multirow{4}{*}{$\begin{array}{l}\text { Factor 3: } \\
\text { Quality conscious }\end{array}$} & 1. Getting very good quality is very important to me. & 0.80 & \multirow[t]{4}{*}{9.54} \\
\hline & $\begin{array}{l}\text { 2. When it comes to purchasing precuts, I try to get the very best or perfect } \\
\text { choice. }\end{array}$ & 0.85 & \\
\hline & 3. In general, I usually try to buy the best overall quality. & 0.71 & \\
\hline & 4. I make special effort to choose the very best quality products. & 0.65 & \\
\hline \multirow{3}{*}{$\begin{array}{l}\text { Factor 4: } \\
\text { Brand } \\
\text { consciousness }\end{array}$} & 1. The higher the price of the product, the better the quality. & 0.73 & \multirow[t]{3}{*}{6.31} \\
\hline & 2. Nice department and specialty stores offer me the best products. & 0.79 & \\
\hline & 3. The most advertised brands are usually very good choices. & 0.78 & \\
\hline \multirow{3}{*}{$\begin{array}{l}\text { Factor 5: } \\
\text { Brand loyal }\end{array}$} & 1. I have favorite brands I buy over and over. & 0.82 & \multirow[t]{3}{*}{5.51} \\
\hline & 2. Once I find a product or brand I like, I stick with it. & 0.83 & \\
\hline & 3. I go to the same stores each time I shop. & 0.65 & \\
\hline \multirow{3}{*}{$\begin{array}{l}\text { Factor 6: } \\
\text { Price conscious }\end{array}$} & 1. I buy as much as possible at sale prices. & 0.78 & \multirow[t]{3}{*}{5.17} \\
\hline & 2. The lowest price products are usually my choice. & 0.72 & \\
\hline & 3. I look carefully to find the best value for the money. & 0.76 & \\
\hline \multirow{3}{*}{$\begin{array}{l}\text { Factor 7: } \\
\text { Impulsive }\end{array}$} & 1. I am impulsive when purchasing. & 0.73 & \multirow[t]{3}{*}{4.26} \\
\hline & 2. Often I make careless purchases I later wish I had not. & 0.70 & \\
\hline & 3. I carefully watch how much I spend. & 0.49 & \\
\hline
\end{tabular}

Table 4 shows logistic regression results for decision-making styles by the five cell-phone switching intentions. Except for FtoF, all other regression models are significant with covariates. First, the FDtoFD model selects price conscious with a positive coefficient (0.33), meaning that priceconscious consumers continuously stay with both foreign and domestic brands. In DtoD, gender and quality conscious are selected and their coefficients are 0.92 and -0.50 , respectively. Since gender is 1 for male and 0 for female, the positive coefficient of gender indicates that more male students than females tend to stay with domestic brands. The negative coefficient of quality conscious shows that respondents who have less quality consciousness stay with local brands. The DtoF model only adopts confused by overchoice (-0.34), which expresses that as brand confusion decreases, the possibility that students will defect from local brands to international brands increases. Conversely, in FtoD, as brand confusion increases (1.05), the willingness of university students to switch from their current foreign mobile phones to domestic brands increases. However, the negative coefficient of brand conscious $(-0.63)$ implies the respondents whom are weakly brand-conscious would rather defect to domestic cell phones. $\mathrm{H} 1$ and $\mathrm{H} 2$ obtain most supports, while brand confusion in FtoD rejects $\mathrm{H} 2$.

Table 4: Logistic regression results for decision-making styles by five cell phone switching intentions

\begin{tabular}{|c|c|c|c|c|c|}
\hline \multirow[b]{2}{*}{ Variables } & \multicolumn{5}{|c|}{ Switching Intentions } \\
\hline & $\begin{array}{l}\text { FDtoFD } \\
(n=169)\end{array}$ & $\begin{array}{l}\begin{array}{l}\text { FtoF } \\
(n=223)\end{array} \\
\end{array}$ & $\begin{array}{l}\text { DtoD } \\
(n=38)\end{array}$ & $\begin{array}{l}\text { DtoF } \\
(n=128)\end{array}$ & $\begin{array}{l}\text { FtoD } \\
(n=26)\end{array}$ \\
\hline $\begin{array}{l}\text { Constant } \\
\text { Gender }\end{array}$ & -2.11 & -0.48 & -1.36 & -0.17 & -4.95 \\
\hline $\begin{array}{l}\text { Gender } \\
\text { Education level }\end{array}$ & & & $0.92 *$ & & \\
\hline Quality conscious & & & $-0.50 *$ & & \\
\hline Brand conscious & & & & & - $0.63^{*}$ \\
\hline Fashion and recreational conscious & & & & & \\
\hline Price conscious & $0.33^{*}$ & & & & \\
\hline Impulsive & & & & & \\
\hline Confused by overchoice & & & & $-0.34 *$ & $1.05 * *$ \\
\hline Brand loyal & & & & & \\
\hline Chi-square & $5.75^{*}$ & N/A & $11.43 * *$ & $6.13 *$ & $15.13 * *$ \\
\hline Correct classification (\%) & 71.2 & 61.7 & 93.5 & 78 & 95.5 \\
\hline
\end{tabular}


Table 5 shows logistic regression results for switching intention for shoe brands. In FDtoFD, students with low fashion-and-recreation consciousness $(-0.46)$ who currently own foreign and domestic brands tend to retain them. Also, price-conscious (0.32) students would stay with them, as would those with choice confusion (0.44). The FtoF model has two significant covariates: fashion-and-recreation consciousness (0.77) and confused by overchoice (-0.39). Respondents with a high preference for novelty and recreation, or low choice confusion are inclined to retain their preference for foreign sports shoes. In DtoD, the negative coefficients of fashion-and-recreation consciousness $(-0.47)$ and price-conscious (-0.33) mean respondents with little fashion-and-recreation consciousness or low price consciousness would continue buying local brands of sports shoes. In DtoF, the significant covariate (gender $=0.49$ ) implies that males would abandon their domestic brands to purchase foreign brands, while for the FtoD model, the reverse trend exists (gender $=-1.23$ ); that is, females are likely to shift from foreign brands to domestic brands. $\mathrm{H} 1$ and $\mathrm{H} 2$ are almost supported but brand confusion in the FtoF model rejects $\mathrm{H} 1$.

Table 5: Logistic regression results for decision-making styles by five sports shoes switching intentions

\begin{tabular}{|c|c|c|c|c|c|}
\hline \multirow[b]{2}{*}{ Variables } & \multicolumn{5}{|c|}{ Switching Intentions } \\
\hline & $\begin{array}{l}\text { FDtoFD } \\
(\mathrm{n}=151)\end{array}$ & $\begin{array}{l}\text { FtoF } \\
(n=141)\end{array}$ & $\begin{array}{l}\text { DtoD } \\
(n=104)\end{array}$ & $\begin{array}{l}\text { DtoF } \\
(n=171)\end{array}$ & $\begin{array}{l}\text { FtoD } \\
(n=17)\end{array}$ \\
\hline Constant & -2.23 & -1.14 & 0.86 & -1.14 & -3.06 \\
\hline Gender & & & & $0.49 * *$ & $-1.23 *$ \\
\hline \multicolumn{6}{|l|}{ Education level } \\
\hline \multicolumn{6}{|l|}{ Quality conscious } \\
\hline \multicolumn{6}{|l|}{ Brand conscious } \\
\hline Fashion and recreational conscious & $-0.46 * *$ & $0.77 * *$ & $-0.47 * *$ & & \\
\hline Price conscious & $0.32 *$ & & $-0.33^{*}$ & & \\
\hline \multicolumn{6}{|l|}{ Impulsive } \\
\hline Confused by overchoice & $0.44 * *$ & $-0.39 *$ & & & \\
\hline \multicolumn{6}{|l|}{ Brand loyal } \\
\hline Chi-square & $20.90 * * *$ & $30.74 * * *$ & $9.30 * * *$ & $7.25 * *$ & $5.32 *$ \\
\hline Correct classification (\%) & 74.30 & 75.80 & 82.20 & 70.70 & 97.10 \\
\hline
\end{tabular}

\section{Discussion}

Gender emerges as a significant factor for switch intention. For mobile phones, male students prefer local brands. In terms of communications technology, previous studies have discovered that males favor communications technology for functional purposes, whereas females primarily use their phones to keep in contact with people they value (Lemish \& Cohen, 2005: 518-519; Rees \& Noyes, 2007). In recent years, Chinese cell-phone makers have focused on designing highperformance and affordable products to meet local needs. For instance, Xiaomi tried to rebuild the image Chinese-made mobile phones; the Xiaomi cell phone has been praised as a revolutionary, high-performance, low-priced smart phone (Srivastava, 2014). This strategy proved effective for those university students with a limited budget.

In terms of sports shoes, male students prefer switching from local to foreign brands, while female students would rather turn to local brands from overseas brands. Wong (2014) suggested men in China tend to attach more importance to traditional designs and women favor trendiness of footwear. In FtoD, nine of 17 respondents selected Chinese sportswear brands, Li-Ning and Anta, as their future brands. For example, Li-Ning has been devoted to product design and once gained market share from foreign brands with bustling demand. However, fashion trends created by foreign brands like ZARA and H\&M quickly reclaimed market share due to Li-Ning's unsatisfactory fashion designs (Bao, 2013). After all, 17 respondents is a small portion of 584 respondents.
Chinese domestic brands still require well-developing design capabilities to increase market share.

Quality consciousness has a significant effect on cell phone switching intention. Only consumers who purchase lowquality products consider local brands as their only choice. In comparison with Chinese brands, foreign brands are traditionally perceived as having higher quality (Sin et al., 2000). According to Ding (2013: 141-142), 53.1\% of Chinese respondents preferred local grocery products, but only $17.4 \%$ preferred domestic mobile phones. Therefore, the quality of Chinese high-tech products requires improvement.

Brand-conscious respondents would be less likely to change their mobile phones from foreign brands to local brands. To reduce perceived risk, consumers tend to acquire well-known brands (Chang, Cheung \& Lai, 2005; Yu, Fu, Cao, Li, Xu \& $\mathrm{Hu}, 2011:$ 1082). Brand-conscious consumers believe that high price is indicative of good quality, which may drive their intention to stay with foreign brands. In contrast, less brandconscious phone buyers can easily switch from foreign to domestic phones.

Fashion-and-recreation consciousness is significant only for sports shoes. First, young consumers with high fashionand-recreation consciousness would remain with foreign brands. Wearing a sports shoe with a unique aesthetic or external appearance reflects individual personality and taste (Johnson \& John, 2001: 207-208). Nike, for example, officially sponsored the Beijing Olympic Games in 2008, 
making its brand fashionable and associated with recreation in the Chinese footwear market (Pitt, Parent, Berthon \& Steyn, 2010: 283). Next, consumers who are fashion-andrecreation conscious have a negative attitude towards local brands. Generally, local brands still lack a fashionable image when compared to foreign brands (Ding, 2013: 219). Students who favor fashion and recreation never consider purchasing domestic sports shoes.

Price conscious consumers would buy good-quality products only when they are reasonably priced. They search for brands that offer good price value (Kasper, Bloemer \& Driessen, 2010: 11-19). Therefore, once they perceive a product as a bargain, they would turn to this product regardless of its origin. Conversely, low price, not good price value, still retains low price-conscious buyers for domestic sportswear.

Confused by overchoice consumers are likely to downsize their considerations, retain the status quo, reduce their information searches, postpone searches, purchase what others have bought, or delegate purchase decisions (Kasper $e t$ al., 2010: 22). The finding, however, shows highly choiceconfused consumers may defect from foreign phones to local phones. Over the past few years, along with the fall of some global brands in China's cell phone market, domestic brands have gained market share. In this study, most brand-confused students own Nokia cell phones and would purchase HTC and Xiaomi phone in the future. Regardless of low prices, local brands have managed to build market share with feature-rich, multi-Subscriber Identity Module (SIM) smart phones. Additionally, some domestic brands work with local marketing channels to promote their phones. This selling atmosphere in China's cell phone market may draw these brand-confused students to move from foreign brands to highly recommended domestic smart phones.

For sports shoes, respondents with little confusion in the context of excessive choice tend to remain with foreign brands, while those who are easily confused prefer holding both local and foreign brands. Bao (2013) once commented that to rapidly expand, domestic sportswear brands show so many similarities in product design, logo and even in marketing strategies. Therefore, customers with little choice confusion stay with fashionable, high-quality foreign brands, while highly confused buyers retain their original choice.

\section{Conclusions and suggestions}

This study empirically explores the effects of decisionmaking styles of university students on switching intention in terms of foreign and domestic brands. The findings show impulsiveness and brand-loyalty do not significantly influence switching or retaining intention. Basically, domestic brands attract low brand-conscious and high choiceconfused buyers from foreign brands and retain low qualityconscious, low fashion-and-recreational-conscious and low price-conscious customers. In contrast, foreign brands can retain consumers who are highly conscious of fashion and recreation and keep and draw customers with low choice confusion. High price-conscious and high brand-confused consumers retain their allegiance to foreign and domestic brands and seek bargains (Table 6).

\section{Table 6: Summary of influence of decision-making styles on switching intention}

\begin{tabular}{|c|l|l|}
\hline Currently own & \multicolumn{1}{|c|}{ Domestic Brands } & \multicolumn{1}{c|}{ Foreign Brands } \\
\hline Domestic Brands & $\begin{array}{l}\text { Quality conscious (p-) } \\
\text { Price conscious (s-) } \\
\text { Fashion and recreational conscious (s-) }\end{array}$ & Confused by overchoice (p-) \\
\hline Foreign Brands & $\begin{array}{l}\text { Confused by overchoice (p+) } \\
\text { Brand conscious (p-) }\end{array}$ & $\begin{array}{l}\text { Fashion and recreational conscious (s+) } \\
\text { Confused by overchoice (s-) }\end{array}$ \\
\hline $\begin{array}{c}\text { Domestic and foreign brand } \\
\text { retention }\end{array}$ & $\begin{array}{l}\text { Price conscious (p+, s+) } \\
\text { Confused by overchoice (s+) } \\
\text { Fashion and recreational conscious (s-) }\end{array}$ \\
\hline
\end{tabular}

Note. $(\mathrm{p})=$ cell phone; $(\mathrm{s})=$ sports shoes; $(+)=$ positive effect; $(-)=$ negative effect

The following are the managerial implications of findings. For local brands, Chinese consumers habitually calculate price value when making purchases; therefore, local brands should offer products of high quality at low prices to highlight price value to university students. Next, domestic brands constantly invest in $R \& D$ to meet local needs. Although Chinese consumers attach great importance to multifunction cell phones and fashion for sportswear, local brands should improve quality and the designs for their goods to meet specific needs and further establish brand equity. For instance, mobile phones with high-efficiency speakers and four LED lights cater to the needs of Chinese farmers, and local brands can be differentiated from foreign brands. Last, to acquire consumers who care about fashion and recreation, marketers should add novel hedonic factors to their products, such as sports sponsorship.

To attract choice-confused consumers, foreign brands may expand their customer base to establish reference groups by launching a full range of products. For example, to cater to the wide consumer base in China, Samsung China Electronics has a wide selection of products, ranging from high-end to low-end smart phones (Euromonitor International, 2013). Moreover, they should build interactive brand channels, such as official websites and Computer, Communication, Consumer (3C) stores, to access quality-conscious consumers. Once they acknowledge the high value of these products sold at affordable prices, these consumers will accept them as high price-value goods. 
For all brands, retaining brand-confused customers with preferential packages would be an effective strategy in China. A value-added strategy should meet the needs of locals and not be overused. Also, brands should always be aware of changes in market share. One brand's decline is another's opportunity. Last, being cognizant of the decision-making styles of customers relative to a product may result in loyal customers and prevent defections. Companies should know which styles their target consumers apply when making purchases and design their marketing strategies accordingly.

This study has a limitation. This study mainly refers to decision-making styles on switching intention from domestic brands to international brands. However, on some occasions, the animosity and ethnocentrism of Chinese consumers significantly affect their intent to purchase imported products (Ishii, 2009). Based on Ding's investigation (2013), nationalism and patriotism are at play in China. These two factors may also affect brand switching and retention of Chinese consumers. The future studies can develop a complete research model of animosity and ethnocentrism on consumers' switching intention.

\section{References}

Ajzen, I. 1991. 'The theory of planned behavior', Organizational Behavior and Human Decision Processes, 50(2): 79-211.

Bandara, W.W.M.C. 2014. 'Consumer decision-making styles and local brand biasness: Exploration in the Czech Republic', Journal of Competitiveness, 6(1):3-17.

Bansal, H.S., Taylor, S.F. \& James, Y.S. 2005. 'Migrating to new service providers: toward a unifying framework of consumers' switching behaviors', Journal of the Academy of Marketing Science, 33(1):96-115.

Bao, Y. 2014. Chinese sports brands see sales slump. [online] http://en.ce.cn/Insight/201301/09/t20130109_24015212.shtml

Batra, R., Ramaswamy, V., Alden, D.L., Steenkamp, J. \& Ramachander, S. 2000. 'Effects of brand local/nonlocal origin on consumer attitudes in developing countries', Journal of Consumer Psychology, 9(2):83-95.

Chang, M.K., Cheung, W. \& Lai, V.S. 2005. 'Literature derived reference models for the adoption of online shopping', Information and Management, 42(4):543-559.

Colgate, M., Tong, V.T., Lee, C.K. \& Farley, J. U. 2007. 'Back from the brink: Why customers stay', Journal of Service Research, 9(1):211-228.

Cordell, V. 1991. 'Competitive context and price as moderators of country of origin preferences', Journal of the Academy of Marketing Science, 19(2):123-128.

Delong, M., Bao, M., Wu, J., Chao, H. \& Li, M. 2004. 'Perception of US branded apparel in Shanghai', Journal of Fashion Marketing and Management, 8(2):141-153.

Dick, A.S. \& Basu, K. 1994. 'Customer loyalty: Toward an integrated conceptual framework', Journal of the Academy of Marketing Science, 22(2):99-113.
Dickson, M.A., Lennon, S.J., Montalto, C.P., Shen, D. \& Zhang, L. 2004. 'Chinese consumer market segments for foreign apparel products', Journal of Consumer Marketing, 21(5):301-317.

Ding, Q.S. 2013. The effects of country of origin, consumer ethnocentrism and consumer animosity on product preference and willingness to buy. De Montfort University e-theses PhD. [online] http://hdl.handle.net/2086/9018

Epsilon, 2013. Epsilon's 2013 consumer loyalty study - China rise of the stylish Chinese consumer. [online] www.epsilon.com/loyalty2013

Euromonitor International, 2013. Mobile Phones in China Category Analysis. [online] www.euromonitor.com/mobile-phonesin-china/report

Fan, Y. 2006. 'The globalization of Chinese brands', Marketing Intelligence \& Planning, 24(4):366-379.

Forbes, 2014. Chinese Sportswear Brand Li-Ning's Long Road to Redemption. [online] www.forbes.com/sites/ckgsb/2014/04/14/ chinese-sportswear-brand-li-nings-long-road-to-redemption/

Ganesh, J., Arnold, M.J. \& Reynolds, K.E. 2000. 'Understanding the customer base of service providers: An examination of the differences between switchers and stayers', Journal of Marketing, 64(3):65-87.

Garbarino, E. \& Johnson, M.S. 1999. 'The different roles of satisfaction, trust, and commitment in customer relationships', Journal of Marketing, 63(2): 70-87.

Hafstrom, J.J., Chae, J.S. \& Chung, Y.S. 1992. 'Consumer decisionmaking styles: comparison between United States and Korean young consumers', The Journal of Consumer Affairs, 26(1):146-158.

Johnson, M.D. \& John, E. 2001. 'Technology, customization and reliability', Journal of Quality Management, 6(1):193-210.

Jurisic, B. \& Azevedo, A. 2011. 'Building customer-brand relationships in the mobile communications market: The role of brand tribalism and brand reputation', Journal of Brand Management, 18(4/5):349-366.

Kasper, H., Bloemer, J. \& Driessen, P.H. 2010. 'Coping with confusion: The case of the Dutch mobile phone market', Managing Service Quality, 20(2):140-60.

Keaveney, S.M. 1995. 'Customer switching behavior in service industries: An exploratory study', Journal of Marketing, 59(2):7182 .

Keller, K.L., 1993. 'Conceptualizing, measuring, and managing customer-based brand equity', Journal of Marketing, 57(1):1-22.

Kim, G., Shin, B. \& Lee, H.G. 2006. 'A study of factors that affect user intentions toward email service switching', Information \& Management, 43(7):884-893.

Kim, S.H. \& Srinivasan, V. 2009. 'A conjoint-hazard model of the timing of buyers' upgrading to improved versions of hightechnology products', The Journal of Product Innovation Management, 26(3):278-290. 
Krishnan, H.S. 1996. 'Characteristics of memory associations: A consumer-based brand equity perspective', International Journal of Research in Marketing, 13(4):389-405.

Laforet, S. \& Chen, J. 2012. 'Chinese and British consumers' evaluation of Chinese and international brands and factors affecting their choice', Journal of World Business, 47(1):54-63.

Lemish, D. \& Cohen, A.A. 2005. 'On the gendered nature of mobile phone culture in Israel', Sex Roles, 7(8):511-521.

Lysonski, S., Durvasula, S. \& Zotos, Y. 1996. 'Consumer decisionmaking styles: A multi-country investigation', European Journal of Marketing, 30(12):10-21.

Mitchell, V.W. \& Bates, L. 1998. 'UK Consumer decision making styles', Journal of Marketing Management, 14(1-3):199-225.

Mokhlis, S. 2009. 'An investigation of consumer decision-making styles of young-adults in Malaysia', International Journal of Business Management, 4(4):140-148.

Naumann, E., Haverila, M., Khan, M.S. \& Williams, P. 2010. 'Understanding the causes of defection among satisfied B2B service customers', Journal of Marketing Management, 26(9):878-900.

Omotayo, O. \& Jachim, A. 2008. 'Customer in the Retention of Mobile Users in Nigeria', African Journal of Business Management, 2(2):26-31.

Pitt, L., Parent, M., Berthon, P. \& Steyn, P.G. 2010. 'Event sponsorship and ambush marketing: Lessons from the Beijing Olympics', Business Horizons, 53(3):281-290.

Pookulangara S., Hawley J. \& Xiao G. 2011. 'Explaining multichannel consumer's channel migration intention using theory of reasoned action', International Journal of Retail \& Distribution Management, 39(3):193-202.

Pritchard, M., Havitz, M. \& Howard, D. 1999. 'Analyzing the commitment-loyalty link in service contexts', Journal of the Academy of Marketing Science, 27(3):333-348.

Rees, H. \& Noyes, J.M. 2007. 'Mobile telephones, computers, and the internet: Sex differences in adolescents' use and attitudes', CyberPsychology \& Behavior, 10(3):482-484.

Reichheld, F.F. \& Sasser, W.E. 1990. 'Zero Defections: Quality Comes to Services', Harvard Business Review, September-October, 68(5):105-111.

Reichheld, F.F. 1996. The Loyalty Effect: The Hidden Force behind Growth, Profits and Lasting Value. Massachusetts, MA: Harvard Business School Press.

Sin, L.Y., Ho, S. \& So, S.L. 2000. 'An assessment of theoretical and methodological development in advertising research on mainland China: A twenty-year review', Journal of Current Issues and Research in Advertising, 22(2):54-69.

Sproles, G.B. \& Kendall, E.L. 1986. 'A methodology for profiling consumers' decision-making styles', Journal of Consumer Affairs, 20(2):267-279.

Srivastava, S. 2014. Xiaomi Mi 3 Android Smartphone: The Quintessential Outperformer-Benchmarking and Performance
Review. [online] www.dazeinfo.com/2014/07/30/xiaomi-mi-3benchmarking-andperformance-review/\#ixzz39909kfJf

Tanksale, D., Neelam, N. \& Venkatachalam, R. 2014. 'Consumer decision making styles of young adult consumers in India', Procedia - Social and Behavioral Sciences, 133(15):211-218.

Taylor, S. \& Todd, P. 1995. 'Decomposition and crossover effects in the theory of planned behavior: A study of consumer adoption intentions', International Journal of Research in Marketing, 12(94):137-156.

Totten, J.W., Lipscomb, T.J., Cook, R.A. \& Lesch, W. 2005. 'General patterns of cell phone usage among college students', Services Marketing Quarterly, 26(3):13-39.

Varki, S. \& Colgate, M. 2001. 'The role of price perceptions in an integrated model of behavioral intentions', Journal of Service Research, 3(3):232-240.

Walsh, G., Mitchell, V.W. \& Hennig, T.T. 2001. 'German consumer decision-making styles', Journal of Consumer Affairs, 35(1):73-95.

Wang, C.L., Siu, N.Y.M. \& Hiu, A.S.Y. 2002. 'Consumer decisionmaking style on domestic and imported brand clothing', European Journal of Marketing, 38(1/2):239-252.

Wang, X.H. \& Yang, Z.L. 2008. 'Does country-of-origin matter in the relationship between brand personality and purchase intention in emerging economies? Evidence from China's auto industry', International Marketing Review, 25(4):458-474.

Wong, B. 2014. China's footwear market. [online] http://chinatrade-research.hktdc.com/business-news/article/China-ConsumerMarket/China-s-footwear-market/ccm/en/1/1X000000/ 1X002MPH.htm

Wong, F.Y. \& Yahyah, S. 2008. 'Influence of brand loyalty on consumer sportswear', International Journal of Economics and Management, 2(2):221-236.

Wu, J. \& Delong, M. 2006. 'Chinese perceptions of western-branded denim jeans: a Shanghai case study', Journal of Fashion Marketing and Management, 10(2):238-250.

Yu, W.W., Fu, K.F., Cao, G.F., Li, J.H., Xu, B. \& Hu, X.H. 2011. 'Understanding the link between consumer decision making style and perceived risk in online business', Advanced Material Research, 204-210: 1082-1085.

Zhou, L. \& Hui, M.K. 2003. 'Symbolic value of foreign products in the People's Republic of China', Journal of International Marketing, 11(2):36-58. 


\section{Appendix 1: List of research items}

I1 $\quad$ Getting very good quality is very important to me.

I2 When it comes to purchasing products, I try to get the very best or perfect choice.

\begin{tabular}{l|l}
\hline I3 & In general, I usually try to buy the best overall quality.
\end{tabular}

I4 I make special effort to choose the very best quality products.

\begin{tabular}{l|l}
\hline I5 & I really don't give my purchases much thought or care.
\end{tabular}

I6 $\quad$ I shop quickly, buying the first product or brand I find that seems good enough.

I7 A product doesn't have to be perfect, or the best, to satisfy me.

I8 $\quad$ The well-known national brands are best for me.

I9 $\quad$ The more expensive brands are usually my choices.

I10 The higher the price of a product, the better its quality.

I11 Nice department and specialty stores offer me the best products.

I12 I prefer buying the best-selling brands.

I13 The most advertised brands are usually very good choices.

\begin{tabular}{l|l}
\hline I14 & I usually have one or more outfits of the very newest style. \\
\hline
\end{tabular}

\begin{tabular}{l|l} 
I15 & I keep my wardrobe up-to-date with the changing fashions.
\end{tabular}

I16 Fashionable, attractive styling is very important to me.

I17 To get variety, I shop different stores and choose different brands.

I18 $\quad$ It's fun to buy something new and exciting.

I19 Shopping is not a pleasant activity to me.

I20 Going shopping is one of the enjoyable activities of my life.

I21 Shopping the stores wastes my time.

I22 I enjoy shopping just for the fun of it.

I23 I make my shopping trips fast.

I24 I buy as much as possible at sale prices.

I25 The lower price products are usually my choice.

I26 1 I look carefully to find the best value for the money.

I27 I should plan my shopping more carefully than I do.

I28 I am impulsive when purchasing.

I29 Often I make careless purchases I later wish I had not.

I30 I take the time to shop carefully for best buys.

I31 I carefully watch how much I spend.

I32 There are so many brands to choose from that often I feel confused.

I33 Sometimes it's hard to choose which stores to shop.

I34 The more I learn about products, the harder it seems to choose the best.

I35 All the information I get on different products confuses me.

I36 I have favorite brands I buy over and over.

I37 Once I find a product or brand I like, I stick with it.

\begin{tabular}{l|l}
\hline I38 & I go to the same stores each time I shop.
\end{tabular}

I39 I change brands I buy regularly. 